10IKC-368

\title{
DYNAMICS OF KIMBERLITE MAGMA ASCENT, INTRUSION AND ERUPTION
}

\author{
${ }^{1}$ Sparks R.S.J., ${ }^{1}$ Buisman, I., ${ }^{1}$ Brooker, R. ${ }^{2}$, Brown R.J., ${ }^{3}$ Field, M., \\ ${ }^{4}$ Gernon, T., ${ }^{1}$ Kavanagh J., ${ }^{1}$ Olgivie-Harris, R and ${ }^{1}$ Schumacher, J.C. \\ ${ }^{1}$ University of Bristol, Bristol, United Kingdom \\ ${ }^{2}$ Durham University, Durham, United Kingdom
}

\section{INTRODUCTION}

This paper reviews evidence and constraints on the dynamics of kimberlite volcanism based on geological evidence, experimental constraints, empirical understanding of volcanic processes and theoretical considerations. Kimberlite magmas are silica-poor ultrabasic magmas rich in volatiles (mostly water and $\mathrm{CO}_{2}$ ) originating at great depths in the mantle (Mitchell, 1986). Due to alteration and incorporation of xenoliths and xenocrysts the nature of kimberlite magmas in terms of magma chemistry and properties, such as temperature, oxidation state, melt compositions, phase equilibria, viscosity, density and volatile inventories is still not well understood and to some extent remains controversial.

\section{MAGMAASCENT}

Like other magmas profound changes in physico-chemical conditions and magma properties are expected when kimberlite magmas decompress during ascent and are either emplaced in near surface hypabyssal intrusions or erupt. These changes likely include entrainment of crustal and mantle xenoliths, resorption of the xenocryst cargo, crystallization induced by cooling and degassing, and changes of oxidation state.

A thermodynamical model of kimberlite magma ascent (Kavanagh and Sparks, 2009) considered four different magma compositions, a basalt and a carbonatite to bound kimberlite behaviour and two intermediate cases. Adiabatic expansion of the melt phase during ascent from $200 \mathrm{~km}$ depth can account for 90 to $140{ }^{\circ} \mathrm{C}$ cooling. Melts with high volatile contents are more corrosive during magma ascent, enriching the melts in $\mathrm{MgO}$ as olivine xenocrysts are assimilated. Kimberlite magma temperatures decrease during ascent up to the onset of rapid pressure-induced olivine crystallization. The models calculate that little olivine assimilation occurs during kimberlite ascent $(<1 \%)$, and this implies the magma composition is set at depth and is not acquired via olivine dissolution. Orthopyroxene assimilation with co-precipitation of olivine may be more efficacious. Latent heat due to predominantly olivine crystallization in the later stages of transport release counteracts cooling mechanisms such as gas exsolution and entrainment of crustal and mantle xenoliths, and in this regime the magma temperature increases as the pressure decreases. At shallow levels gas exsolution and expansion become dominant processes and the magma temperature cools during the final stages of ascent. The models yield shallow magma temperatures consistent with estimates from geothermetric studies (1030-1170 ${ }^{\circ} \mathrm{C}$ ) when the volatile content of the ascending kimberlite magma is less than $10 \mathrm{wt} . \% \mathrm{H}_{2} \mathrm{O}$. Models where 5 wt $\% \mathrm{H}_{2} \mathrm{O}+\mathrm{e} " 5$ wt $\% \mathrm{CO}_{2}$ is exsolved are consistent with observations of 


\section{0 $^{\text {th }}$ International Kimberlite Conference, Bangalore - 2012}

approximately $25 \%$ phenocrysts and $25 \%$ xenocrysts in many kimberlites.

Rates of magma ascent are estimated at several metres per second (Sparks et al., 2006), resulting in ascent times of several hours from the base of the lithosphere. Magmas can accelerate to speeds of a few tens of metres per second close to the surface due to volatile exsolution.

\section{INTRUSION, DIFFERENTIATION, MULTIPLE MAGMA PULSES AND MAGMA MIXING}

Shallow level differentiated kimberlite sills are well known, and include the Wesselton sills and Blufontein sills in Kimberley district, South Africa, and the Snap Lake intrusion, NW Territory, Canada. These sills provide evidence of in situ differentiation, multiple pulses of different composition magmas and magma mixing. Stalling of kimberlite at greater depths seems highly plausible. Stalling may also result in fractional crystallization, loss or gain of xenocrysts and loss of volatiles. Thus a wide variety of kimberlitic derived magmas could form. Examples of differentiated compositions include the Wesselton Sills, which trend towards carbonatites (White et al., 2011), while the Blufontien sills are a classic case of in situ differentiation in thin sills (Dawson and Hawthorne, 1973). The Igwisi Hills kimberlite stalled in the mantle lithosphere with thermal equilibration and incorporation of mantle xenocrysts and xenoliths (Dawson, 1994).

Multiple pulses of kimberlite magmas can form separate geological units or mix during ascent, intrusion and eruption. Evidence for multiple magma batches can be recognised from distinctive geochemistry and mineral assemblages and is common in kimberlite intrusions and pipes. Magma mixing between these units is also common. Examples of these phenomena include Snap Lake (Gernon et al., 2011), AK6 in Orapa district, du Toitspan (Olgivie-Harris et al., 2009) the Wesselton sills (White et al., 2012) and Orapa
(Sarkar et al., 2012). Mutiple pusles with clear breaks in activity are inconsistent with the idea that kimberlite eruptions are single event dramatic explosions.

\section{NEAR SURFACE KIMBERLITE MAGMAS AND MELTS}

The nature of kimberlite magmas in near surface environment of shallow intrusions and eruptions remains contentious. Alteration and suspended xenocrysts provide barriers to interpretation. Reconstructing groundmass compositions to take account of alteration together with high temperature experimental studies at low pressure (Sparks et al., 2009; Brooker et al., 2011) indicate that kimberlite melts are lower in silica $(<25 \%$ and $\mathrm{Mg} 0<20 \%)$ than hithertoo supposed and can approach carbonatitic compositions. However, no experiments have yet succeeded in reproducing kimberlite groundmass mineral assemblages and parageneses, indicting that the hunt for the true nature kimberlite melts remains elusive. Although there is a wide consensus that kimberlite magmas are volatile-rich, the inventory of these volatiles is likewise poorly constrained.

The origin of groundmass serpentine in kimberlites remains controversial with alternative explanations being that they are formed by deuteric reactions related to magmatic fluids (Mitchell, 2008) and alternatively alteration due to circulation of external fluids through highly reactive kimberlite matrix (Sparks et al., 2009). In the former case the very high water masses required to form serpentine have implications for the volatile inventory of kimberlite magmas and, if the alteration occurs in a closed system, for the compositions of erupting kimberlite melts. Mass balances of volatiles provide a significant difficulty for the deuteric hypothesis, although it is recognized that the two hypotheses are not mutually exclusive.

New observations of serpentine in the groundmass of the Igwisi Hills kimberlite supports 


\section{0 $^{\text {th }}$ International Kimberlite Conference, Bangalore - 2012}

alteration from external fluids in an open system. Both lavas and pyroclastic rocks from the Igwisi pyroclastic cones demonstrate formation of groundmass and matrix serpentine from low temperature alteration of olivine and spinel in environments that make involvement of internally generated hydrous fluids implausible.

\section{KIMBERLITE ERUPTIONS}

Changes in magma properties near and at the Earth's surface can be large and rapid (notably degassing), resulting in strong disequilibrium and kinetic controls on property changes. Rapid ascent and decompression of volatile-rich magmas explains the strong tendency of kimberlite eruptions to be explosive. While the occurrence of phreatomagmatic explosive volcanism is likely commonplace, as for other magma types, it does not provide a comprehensive or fundamental exclusive explanation. Thermal remnant magmatism studies (Fontana et al., 2011) are demonstrating that some kimberlite pipes are infilled by high temperature (several hundreds of degrees), observations that are hard to reconcile with phreatomagmatic eruptions. Although volcanism is predominantly explosive, lavas at Igwisi Hills, Tanzania, show that kimberlite magmas can degas and erupt effusively. Igwisi Hills also demonstrates that some kimberlite magmas can have quite high viscosity $(\sim 10$ to $\left.10^{3} \mathrm{~Pa} \mathrm{~s}\right)$ in the near surface environment and during eruption. These high viscosities can be explained by rapoid degassing-induced groundmass crystallization during the eruptive process.

Kimberlite geology is informing a new understanding of processes in volcanic conduits. Once a deep conduit is establish its growth by a variety of mechanical processes means that explosively generated materials (pyroclasts and wall-rock lithics) can become trapped and confined in the conduit, resulting in strong interactions of erupting magma and vent-fill material (Sparks et al., 2006; Gernon et al., 2009; Brown et al., 2009). While some analogies with at surface pyroclastic processes, such as pyroclastic flows and fall-out are useful, the highly confined nature of a deep volcanic vent introduces new processes such as fluidisation, dynamic sintering (Brown et al., 2008) and intense mixing between volcanic jets and concentrated trapped mixtures. Processes such as formation of pyroclastic fills to kimberlite vents and welding (Brown et al., 2008) can lead to blocking of vents and cyclic volcanism.

Kimberlite conduits can reach sufficient depths that large under-pressures in explosive eruptions can result in explosive disintegration of highly stressed wall-rocks that mine out cavities. This process together with the propensity for hot pyroclastic kimberlite to become densely welded can explain the characteristics of root zones and the formation of apparent blind intrusions. Limited occurrences of extra-vent and crater fill lithofacies indicate kimberlite eruptions generate eruptive products that are similar in most respects to those produced by more common magma types.

\section{References}

Brooker, R.J., Sparks, R.S.J., Kavanagh, J. and Field, M. 2011. Volatile solubility in hypabyssal kimberlite magmas: Experiments on natural rock compositions. Bulletin of Volcanology (in press).

Brown, R.J., Buse, B., Sparks, R.S.J. and Field, M. 2008. On welding of pyroclasts from very low viscosity magmas: examples from kimberlite volcanoes. Journal of Geology 116, 354-374.

Brown, R.J., Tait, M., Field, M. and Sparks, R.S.J. 2009. Geology of a complex kimberlite pipe (K2 pipe, South Africa): insights into conduit processes during explosive ultrabasic eruptions. Bulletin of Volcanology 71, 95-112.

Dawson, J.B. 1994. Quaternary kimberlitic volcanism on the Tanzania craton. Contributions to Mineralogy and Petrology, 116 473-485.

Dawson J.B. and Hawthorne JB 1973. Magmatic sedimentation and carbonatitic differentiation in 


\section{0 $^{\text {th }}$ International Kimberlite Conference, Bangalore - 2012}

kimberlite sills at Benfontein, South Africa. Journal of the Geological Society of London 129, 61-85.

Fontana, G., MacNiocaill, C., Brown, R.J, Sparks, R.S.J., and Field, M. 2011. Emplacement temperatures of pyroclastic and volcaniclastic deposits in kimberlite pipes in southern Africa. Bulletin of Volcanology 70, DOI 10.1007/s00445011-0493-9.

Gernon, T., Gilbertson, M.G., Sparks, R.S.J. and Field, M. 2009. The role of gas fluidisation in the formation of massive volcaniclastic kimberlite. Lithos 112S, 438-451.

Gernon, T.M., Field, M. \& Sparks, R.S.J. 2011. Geology of the Snap Lake kimberlite intrusion, NW Territories, Canada: Field observations and their interpretation. Journal of the Geological Society, doi: 10.1144/0016-76492011-056

Kavanagh, J. and Sparks, R.S.J. 2009. Temperature changes in ascending kimberlite magmas. Earth and Planetary Science Letters 286, 404-413.

Ogilvie-Harris, R.C., Field, M. Sparks, R.S.J., and Walter, M.J. 2009. Perovskite from the Dutoitspan kimberlite, Kimberley, South Africa: implications for magmatic processes Mineralogical Magazine, 73, 915-928.
Mitchell, R.H. 1986. Kimberlites: mineralogy, geochemistry, and petrology. Plenum Press, New York, N.Y., pp 442.

Mitchell, R.H. 2008. Petrology of hypabyssal kimberlites: Relevance to primary magma compositions. Journal of Volcanology and Geothermal Research 174 (2008) 1-8

Sarkar, C., Storey, C., Hawkesworth, C.J. and Sparks, R.S.J. Degassing in kimberlite: oxygen isotope ratios in perovskites in explosive and hypabyssal kimberlites. Earth and Planetary Science Letters (in press).

Sparks, R.S.J., Baker, L., Brown, R.J., Field, M., Schumacher, J., Stripp, G. and Walters, A. L. 2006. Dynamics of Kimberlite Volcanism. Journal of Volcanology and Geothermal Research 155, 1848.

Sparks, R.S.J., Brooker, R.A., M. Field, M. Kavanagh, J. Schumacher, J.C., Walter, M.J., and White, J. 2009. The nature of erupting kimberlite melts. Lithos 112S, 429-438.

White, J.L., Sparks, R.S.J., Bailey, K., Barnett, W.P., Matthew Field, M. Lisa and Windsor, L. Kimberlite sills and dykes associated with the Wesselton Kimberlite pipe, Kimberley, South Africa. South African Journal of Geology (in press). 